特 集

\title{
放射線損傷を利用した年代測定
}

\section{フィッション・トラック年代測定の基礎 ーこれまでの経緯と今後の発展の可能性一}

\author{
長谷部徳子 ${ }^{1, \dagger}$, 末岡 茂 $^{2}$, 田上高広 ${ }^{3}$ \\ ${ }^{1}$ 金沢大学環日本海域環境研究センター \\ ${ }^{2}$ 日本原子力研究開発機構東濃地科学センター \\ 3 京都大学理学研究科地球惑星科学専攻 \\ ${ }^{\dagger}$ hasebe@staff.kanazawa-u.ac.jp
}

\begin{abstract}
フィッション・トラック (FT) 法は, 多くの放射年代測定が同位体化学分析を用いているのに比 し， ウランの核分裂によって生じる物質中の線状損傷を可視化し観察するユニークな年代測定法 である。年代測定法としてだけでなく，その特徵を利用して地質試料の $300^{\circ} \mathrm{C}$ 以下の熱履歴の復 元にも利用されている。本稿では FT 法の歴史を再訪し, 今後の FT 法の発展にどのような方向性 がありうるかを紹介する。
\end{abstract}

Key Words: fission-track (FT) dating, geochronology, thermochronology

\section{1. はじめに}

多くの放射年代測定が同位体化学分析を用い ているのに比し，フィッション・トラック (FT) 法は ${ }^{238} \mathrm{U}$ (親核種)の核分裂によって生じる物 質中の線状損傷 (FT：核分裂片の飛跡, 娘核種 に相当）を可視化し観察するユニークな年代測 定法である。 ${ }^{238} \mathrm{U}$ の壊変 (半減期は約 45 億年) のほとんどは $\alpha$ 壊変によるものであり, 核分裂 によるものは，壊変を被る ${ }^{238} \mathrm{U}$ の 100 万分の 1 にも満たないため, 年代測定法の常識からいう と壊変の頻度 (娘核種の生成頻度) が低すぎて 地球上の試料への適用は難しいはずである。し かしながら原子核一つの壞変を捉えることがで きるという特徵により, FT 法の測定対象年代 域は, 試料のウラン濃度や観察面の大きさに依 存するものの, 顕生代を広くカバーする。地球 年代学の教科書 ${ }^{1,2}$ ) では, ルミネッセンス年代 測定法, 電子スピン共鳴 (ESR) 年代測定法と ともに放射線損傷を利用した年代測定法として 分類されている。今となっては多くの手法で可
能となっている単一鉱物粒子の年代測定である が, FT 法はその発展の当初から単一粒子年代決 定が可能であったため, 堆積岩にも適用でき, どのような年代值の粒子が含まれているか調べ られることが大きな利点であった ${ }^{3,4)}$ 。

FT 法のもう一つの大きな特徵は, 地質試料 の熱履歴の復元が可能な点である。蓄積した FT は熱により消失するが, FT の消失に必要な 温度・時間条件は釷物種に依存している。冷却 を被った試料の場合, 冷却に伴い FT の蓄積が 始まり, 年代值はある温度以下になって以来 経過した時間（冷却年代, cooling age) を示す。 一旦冷えて FT が蓄積された試料が再加熱を受 け, 既存の FT が全てなくなると, 放射年代時 計がリセットされるため, 冷却年代は再加熱イ ベントの時期を示す。FT 年代のリセットは比 較的低い温度で起こるため, 地表から地下数 $\mathrm{km}$ 程度の地殼浅部における熱イベントの研究 に用いられている。ただし，この消失が完全に 行われないと, mixed-age と称せられる, 何か のイベントに対応しない年代値を得ることにな 
る $^{5)}$ 。この現象は, 同位体化学分析に基づく他 の年代測定手法でも生じることである。FT 法の 場合は, FT の長さ分布を計測することにより, 得られた数值の意味を紐解くとともに，その特 徵を利用して熱履歴の復元に利用されている。

FT 法を紹介する論文は多数あり, 最近の ものでは手法の歴史についてまとめた Hurford $(2019)^{6)}$ や，実験手順の紹介に主眼をおいた Kohn et al. $(2019)^{7)}$ がある。日本語のものとし ては，第四紀の火山噴出物に焦点を絞ったもの ではあるが壇原 $(1995)^{8)}$ にまとめられている。 山地の隆起・削剥など地殼浅部の熱履歴解析に ついては末岡・田上 $(2019)^{9)}$ に紹介されている。 本稿では FT 法の初期の成果を振り返るととも に, 今後の FT 法の発展にどのような方向性が ありうるかを紹介する。な㭴最新の FT 法の技術 については本特集号の末岡ほかを参照されたい。

\section{2. フィッション・トラック（FT）とは}

質量数が大きい原子核を持つ核種は $\alpha$ 線や $\beta$ 線などを放出して安定な核種に壞変する場合 がある。そのような原子核のなかには, 稀に 自発的に核分裂を起こすものがある。核分裂片 は正電荷をもっており，核種が含まれていた物 質を構成する原子の電荷を乱しながら運動エネ ルギーを失うまで移動する。電荷を乱された原 子は隣り合う原子同士でさらに反発し, 結果 として絶縁性固体中には非晶質な線状損傷が 生成され ${ }^{10)}$ ，核分裂飛跡もしくはフィッショ ン・トラック (FT) と呼ばれている。またその 損傷部分は, 元の構造を保持している周辺部と 比べて化学的エッチングされやすいという特徴 を持つ ${ }^{10)}$ 。損傷部分の径や長さは核分裂時に 放出されるエネルギーや FT が生じる物質に依 存している。例えば ${ }^{238} \mathrm{U}$ 起源の FT では, 電子 顕微鏡による観察から径は2 30 $\mathrm{nm}^{11,12)}$ の值 が報告されている。長さはエッチングをした FTによる観察で 10～20 $\mu \mathrm{m}$ の值が報告されて いる ${ }^{13-16)}$ (Fig. 1)，またFTは在るべき場所か ら原子が移動したことによる結晶構造の乱れで

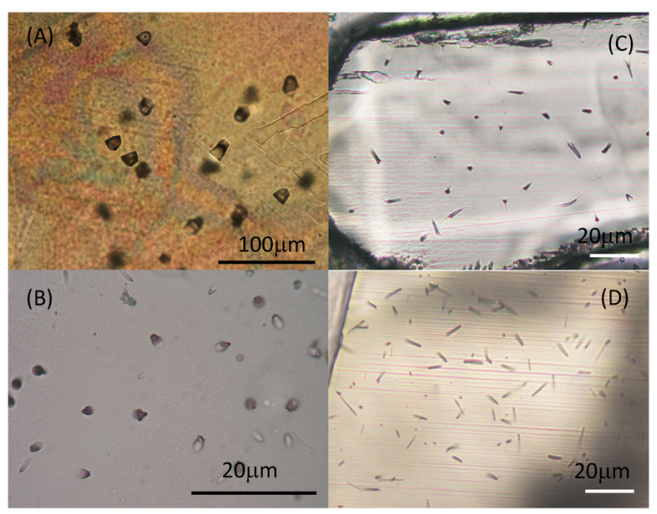

Fig. 1 Etched fission tracks in various media. (A) Biotite from Slyudyanka, Russia (etched for $4 \mathrm{~min}$ in $48 \%$ $\mathrm{HF}$ at room temperature). (B) Volcanic glass from Nagano, Japan (induced tracks, etched for $30 \mathrm{~s}$ in $24 \% \mathrm{HF}$ at $\left.30^{\circ} \mathrm{C}\right)$. (C) Apatite from Fish Canyon Tuff, USA (etched for $20 \mathrm{~s}$ in $5 \mathrm{M} \mathrm{HNO}_{3}$ at $20^{\circ} \mathrm{C}$ ). (D) Zircon from Buluk Member Tuff, Kenya (etched for $45 \mathrm{~h}$ in $\mathrm{KOH}: \mathrm{NaOH}=1: 1$ eutectic etchant at $230^{\circ} \mathrm{C}$ (Color online).

あるため, 拡散により原子が元の位置に戻ると FT は消失する。

自然下で発生するFTは自発 FT(spontaneous fission-track), もしくは化石 FT(fossil fission-track) と呼ばれている。天然の試料ではFTはほとん どが ${ }^{238} \mathrm{U}$ 由来であるため, 地球科学では年代 測定に利用され，FT 年代測定法もしくは単に FT 法とよばれている。また ${ }^{238} \mathrm{U} よ り$ 軽い ${ }^{235} \mathrm{U}$ や $^{232} \mathrm{Th}$ では天然での核分裂はほとんど発生し ないが，原子核に中性子を照射すると，核分 裂を誘導することができ，このようにできた FT は誘導FTもしくは誘発FT(induced fission track）と呼ばれる。 ${ }^{235} \mathrm{U}$ は主として熱中性子に よって, ${ }^{232} \mathrm{Th}$ は速中性子によって誘導 $\mathrm{FT}$ を生 じるので，照射する中性子のエネルギーを制限 することによって, 試料中のウランやトリウム の分布を調べるのに利用される ${ }^{17)}$ 。

\section{3. $\mathrm{FT}$ 年代測定}

本章では, FT 法の実験手順に沿って，主な 工程にまつわる従来の経緯と現在における考 え方を紹介する。FT法では，採取した地質試 
料 (多くの場合は岩石試料) を対象に，鉱物分 離, 前処理（鉱物マウントの作成, FT のエッ チング), FT の観察・測定, ウラン濃度測定を 行うことで年代值を得る。分析手順の詳細は, Tagami et al. (1988) ${ }^{18)}$, 檀原 $(1995)^{8)}$, Donelick et al. $(2005)^{19)}$, Kohn et al. $(2019)^{7)}$ などを参照 されたい。

\section{$3 \cdot 1$ 分析対象鉱物}

一般的によく利用されている分析対象として はウランの含有量が多いジルコン，アパタイト (燐灰石)，スフェーンもしくはチタナイト（く さび石，もしくはチタン石)，ガラス(火山ガ ラスやテクタイト，考古遺物など) が挙げられ

Table 1 Minerals less common for fission-track dating but for which fission-tracks were observed.

\begin{tabular}{|c|c|c|c|}
\hline & fossil FT & etchant & reference \\
\hline \multirow{2}{*}{ quartz } & & $\mathrm{KOH}$ sol, $150^{\circ} \mathrm{C}$ & 21) \\
\hline & & $48 \% \mathrm{HF}, 23^{\circ} \mathrm{C}$ & 21) \\
\hline orthoclase & & $48 \% \mathrm{HF}, 23^{\circ} \mathrm{C}$ & 21) \\
\hline microcline & 0 & $48 \% \mathrm{HF}, 23^{\circ} \mathrm{C}$ & 21) \\
\hline \multirow{4}{*}{ biotite } & & & \\
\hline & 0 & $48 \% \mathrm{HF}, 20-25^{\circ} \mathrm{C}$ & 21), 23) \\
\hline & 0 & $24 \% \mathrm{HF}$ & 24) \\
\hline & & $6 \% \mathrm{HF}, 60^{\circ} \mathrm{C}$ & 25 (induced tracks) \\
\hline muscovite & 0 & $48 \% \mathrm{HF}, 20-40^{\circ} \mathrm{C}$ & 21), 25 (indued tracks) \\
\hline chlorite & 0 & $48 \% \mathrm{HF}, 23^{\circ} \mathrm{C}$ & 21) \\
\hline clinochlore & & $48 \% \mathrm{HF}, 23^{\circ} \mathrm{C}$ & 21) \\
\hline penninite & & $48 \% \mathrm{HF}, 23^{\circ} \mathrm{C}$ & 21) \\
\hline lepidolite & 0 & $48 \% \mathrm{HF}, 23^{\circ} \mathrm{C}$ & 21) \\
\hline margarite & & $48 \% \mathrm{HF}, 23^{\circ} \mathrm{C}$ & 21) \\
\hline \multirow{2}{*}{ phlogopite } & 0 & $48 \% \mathrm{HF}, 20-25^{\circ} \mathrm{C}$ & 21), 23) \\
\hline & & $40 \% \mathrm{HF}, 27^{\circ} \mathrm{C}$ & 25 (induced tracks) \\
\hline vermiculate & & $24 \% \mathrm{HF}, 40^{\circ} \mathrm{C}$ & 25 (induced tracks) \\
\hline talc & & $48 \% \mathrm{HF}, 23^{\circ} \mathrm{C}$ & 21), 25 (indued tracks) \\
\hline pyroxene & & $\mathrm{KOH}$ sol, $220^{\circ} \mathrm{C}$ & 21) \\
\hline spodumene & & $48 \% \mathrm{HF}, 23^{\circ} \mathrm{C}$ & 21) \\
\hline hornblende & 0 & $48 \% \mathrm{HF}, 20-60^{\circ} \mathrm{C}$ & 21), 23) \\
\hline allanite & 0 & $50 \mathrm{~N} \mathrm{NaOH}, 140^{\circ} \mathrm{C}$ & 26) \\
\hline epidote & 0 & $50 \mathrm{~N} \mathrm{NaOH}, 140^{\circ} \mathrm{C}$ & 26) \\
\hline beryl & & $\mathrm{KOH}$ sol, $150^{\circ} \mathrm{C}$ & 21) \\
\hline tonrmaline & & $\mathrm{KOH}$ sol, $150^{\circ} \mathrm{C}$ & 21) \\
\hline \multirow{2}{*}{ olivine } & & $48 \% \mathrm{HF}, 23^{\circ} \mathrm{C}$ & 21) \\
\hline & & $\mathrm{KOH}$ sol, $220^{\circ} \mathrm{C}$ & 21) \\
\hline \multirow{2}{*}{ garnet } & O & $50 \mathrm{~N} \mathrm{NaOH}, \quad 140^{\circ} \mathrm{C}$ & 26) \\
\hline & & $\mathrm{KOH}$ sol, $150^{\circ} \mathrm{C}$ & 21) \\
\hline topaz & & $\mathrm{KOH}$ sol, $150^{\circ} \mathrm{C}$ & 21) \\
\hline autunite & 0 & $10 \% \mathrm{HCl}, 23 \mathrm{C}$ & 21) \\
\hline calcite & & $10 \% \mathrm{HCl}, 23 \mathrm{C}$ & 21) \\
\hline barite & & $\mathrm{HNO}_{3}, 100^{\circ} \mathrm{C}$ & 21) \\
\hline gypsum & & $5 \% \mathrm{HF}, 23^{\circ} \mathrm{C}$ & 21) \\
\hline fluorite & & $98 \% \mathrm{H}_{2} \mathrm{SO}_{4}, 23^{\circ} \mathrm{C}$ & 21) \\
\hline halite & & Ethanol \& $3 \mathrm{~g} / \mathrm{HgCl} 2$ & 21) \\
\hline
\end{tabular}

る ${ }^{6)}$ 。Fig. 1 にエッチングした FT の写真を紹介 する。FT 法の黎明期には，最初に化石 FT（自 発 FT）が発見された雲母類 ${ }^{20)}$ に加え，緑泥石 類，かんらん石や方解石など色々な鉱物が FT を記録する媒体となり得ることが示されてい

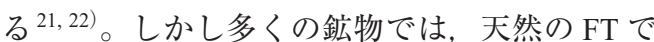
はなく人工的にカリフォルニウムの核分裂片 を鉱物に作用させたトラックを観察していた ため，現在に至るまで，これらの鉱物が地質時 計として利用された例はほとんどない。Table 1 に初期の頃に FT 観察を試みられた鉱物のリス トを付したので，基礎実験に興味ある向きは参 考にされたい。

\section{$3 \cdot 2$ 鉱物分離}

$\mathrm{FT}$ 年代測定法では対象とする鉱物を単離し て分析に処すのが一般的である。この理由には 二つあり，（1）対象となるウランを含む鉱物の 中にはジルコンのように微量にしか含まれてい ない鉱物があるため，対象鉱物を濃集させる必 要があること，（2）親元素であるウランの定量 に原子炬での熱中性子照射が用いられており， それを行うにあたり，無用な放射化を防ぐ必要 があることが挙げられる。

対象鉱物の分離は地質学では古くから行わ れており，粉砕，サイズ選別ののち，比重，磁 性，鉱物の形に基づき行われる7,18) (Fig. 2)。 古典的な方法からの変化としては，岩石粉砕に 高電圧を利用した機器（Serflag 社）も選択肢の 一つとなったことが挙げられる ${ }^{27)}$ 。比重分離 に用いる重液は 30 年前には毒性の強いものが 主流だったが最近はポリタングステン酸ナトリ ウム $(\mathrm{SPT})^{28)}$ や $\mathrm{LST}^{29)}$ が主として利用されて いる。またネオジム磁石の登場により, Isodynamic Separator を利用しなくても，弱磁性鉱物 を選り分けられるようになった。

\section{$3 \cdot 3$ エッチングと FT の観察・計数}

年代測定には自発 FT の正確な認定が重要に なる。Fleischer and Price $(1964)^{21)}$ に挙げられて 


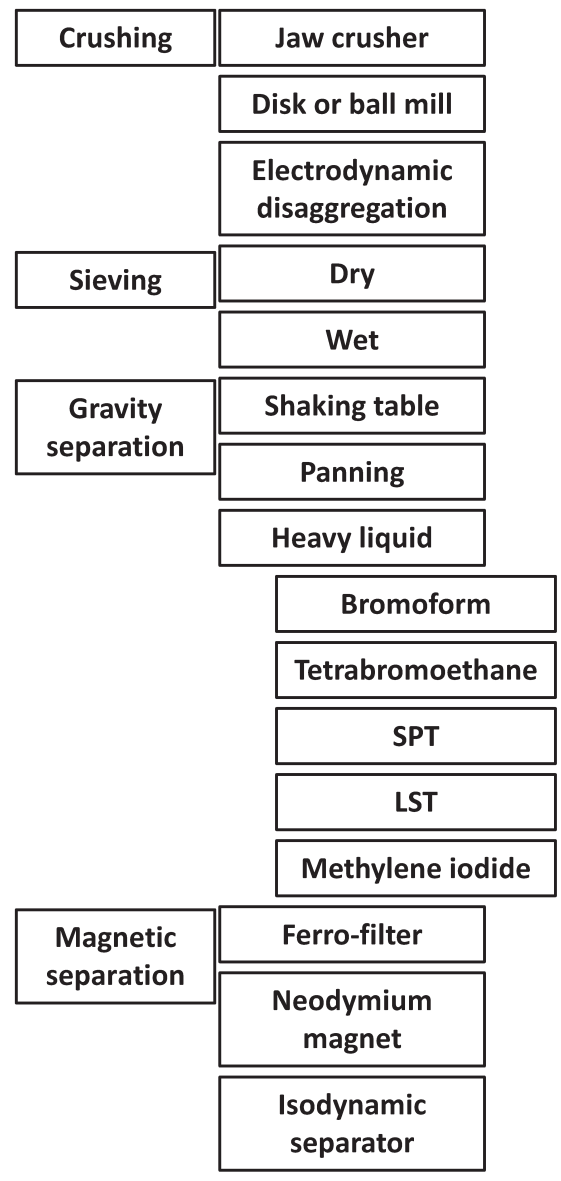

Fig. 2 Mineral separation processes.

いる FT の認定基準は以下のように示されてい る。（1）線状かつ直線的な欠陥であること，(2) その方位はランダムであること（配向していな い), (3) 線構造はある一定の長さの範囲に収ま ること，(4)加熱すると消失すること。これは 現在の理解でも変わっていない。FT の観察は 電子顕微鏡から始まったが ${ }^{11)}$, その後, 鉱物 ごとに適切なエッチング溶液を利用することに より光学顕微鏡での FT 観察・計数が可能とな り，現在年代測定を目的とした FT 観察は，ほ とんどエッチングを施して行われている。エッ チングをどこまで実施するかは年代測定結果を 左右する重要な項目である。エッチングが足り ないと計数するべき FT を見逃し年代を若く見 積もってしまう。一方エッチングしすぎると,
観察面を横切るトラックに関与するウランの個 数を見誤ることになるし，エッチングによって FT の消失や結合が発生するため, 正確な年代 決定のためにはエッチングのしすぎは避けるべ きである。どのようにエッチングを行うべきか は, FT 法でよく利用されるアパタイト及びジ ルコンではよく決まっている ${ }^{30-34)}$ 。特にジル コンでは粒子中にウラン濃度の不均質がある場 合，場所によってエッチングのされ方が異なる ので，均質なウラン濃度を持った部分（すなわ ち FT 密度が均質な部分) を対象にエッチング を行う必要がある。火山ガラスやスフェーンに ついては, アパタイト・ジルコンほど充実した 研究は行われていないが，年代決定等に利用さ れた実績があり(スフェーン 16,35-37), 火山ガラ $\left.ス^{38-40)}\right)$ ，その際に利用されたエッチング条件 を参考にできる。基礎研究としては電子顕微鏡 による観察 ${ }^{12,41,42)}$ や，原子間力顕微鏡による 観察 ${ }^{43-45)}$ も続けられている。末岡ほか (本特集 号) で紹介されている通り，FTの自動計測を 導入することによって，適切にエッチングされ た試料の FT 認定については経験によらない計 数が可能になりつつあるが, 試料をどのような 状態にまでエッチングするかが，大きくその結 果を左右することに留意する必要がある。

\section{$3 \cdot 4 \quad \mathrm{FT}$ 年代式とウラン濃度の見積もり}

一般的な同位体濃度測定に基づく放射年代測 定は, 単位体積あたりの対象原子数に基づき年 代式を構築する。外部と核種のやり取りがない 閉鎖系を仮定すると，ある時刻 $t$ における単位 体積あたりの親核種数 $P$ は, 壊変定数 $\lambda$ を用い て以下の式で表される。

$$
d P / d t=-\lambda P
$$

この微分方程式を解くと以下の式が得られる。

$$
P=P_{0} e^{-\lambda t}
$$

ただし $P_{0}$ は時刻 $t=0$ における親核種数である。 放射壊変起源の娘核種数 $N^{*}$ は, 親核種の減少 
量 $P_{0}-P$ に等しいため, $t=0$ における娘核種数 $N$ について下記の式が得られる。

$$
N=N_{0}+N^{*}=N_{0}+P\left[e^{\lambda t}-1\right]
$$

上式に倣うと, 時刻 $t=0$ では FT 数は 0 とみな せるため, FT 法の年代式は以下のように表せ る。

$$
D=\frac{\lambda_{f}}{\lambda_{238}}{ }^{238} \mathrm{U}\left(e^{\lambda t}-1\right)
$$

ここで D は単位体積あたりの FT 数, ${ }^{238} \mathrm{U}$ は単 位体積あたりのウランの個数, $\lambda_{\mathrm{f}}$ は ${ }^{238} \mathrm{U}$ の自 発核分裂の壊变定数, $\lambda_{238}$ は ${ }^{238} \mathrm{U}$ の全壊变定数 である。

一方 FT 法は面積あたりの FT の計数結果か ら単位体積あたりの FTの数を見積もる必要が あるため

$$
D=k G \rho_{s}
$$

ここで $\rho_{s}$ は単位面積当たりの FT の個数, $k G$ は 面積当たりの FT 数から体積あたりの $\mathrm{FT}$ 数を 算出するために必要な係数であり，(1)主として FT の長さに起因する registration factor $(k)^{46)}$ と, (2)観察する面に対して ${ }^{238} U$ がどのように分布 しているかを示す geometry factor $(G)^{8)}$ から成 る (Fig. 3)。FTの長さは，核分裂片が物質内 をどれくらい移動するとそのエネルギーを失う か，またどのような構造の乱れがエッチングに より可視化されるかに依存しており，観察鉱物 ごとに異なっている。したがって $k$ も観察鉱物 ごとに異なっている。また観察面とウランの分 布による係数 $G$ は，観察面の下部に分布する ${ }^{238} \mathrm{U}$ のみが面積当たりの FT 数に貢献する結晶 の外形面 $(2 \pi$ 面と呼ばれる) を観察する場合に 比べて，観察面の上下にある ${ }^{238} \mathrm{U}$ が面積当た りの FT 数に貢献する内部面 $(4 \pi$ 面と呼ばれる) を観察する場合だと半分になる。 $2 \pi$ 面と $4 \pi$ 面 の間にある部分は， $G$ の見積もりの都合上，通 常は年代決定に利用しない。

(4) 式と (5) 式より，一般的な FT 法の年代式 は以下のように与えられる。

$$
t=\frac{1}{\lambda} \ln \left(k G \frac{\lambda_{238}}{\lambda_{f}} \frac{\rho_{s}}{{ }^{238} \mathrm{U}}+1\right)
$$

年代值の誤差は, 式で用いられる係数の誤 差, ウランの個数の誤差, FT の計数の誤差か ら，一般的な誤差伝搬の考え方で求める。

$$
\left(\frac{\sigma t}{t}\right)^{2}=\left(\frac{\sigma x}{x}\right)^{2}+\left(\frac{\sigma^{238} \mathrm{U}}{{ }^{238} \mathrm{U}}\right)^{2}+\left(\frac{\sigma \rho_{s}}{\rho_{s}}\right)^{2}
$$

ここ $\frac{\sigma x}{x}$ では ${ }^{238} \mathrm{U}$ と $\rho_{\mathrm{s}}$ 以外の係数をまとめて 誤差を評価したもので，この(7)式より

$$
\sigma t=t \sqrt{\left(\frac{\sigma x}{x}\right)^{2}+\left(\frac{\sigma^{238} \mathrm{U}}{{ }^{238} \mathrm{U}}\right)^{2}+\left(\frac{\sigma \rho_{s}}{\rho_{s}}\right)^{2}}
$$

FT の計数の誤差は放射壊変がポアソン分布 に従うことから以下のように与えられる ${ }^{47)}$

$$
\frac{\sigma \rho_{s}}{\rho_{s}}=\frac{1}{\sqrt{N_{s}}}
$$

ここで $N_{s}$ は計数した自発 FT の数である。

親元素であるウラン濃度の測定は初期の頃 （1960 年代）から放射化分析によって行って おり ${ }^{21)}$ ，熱中性子照射により生じる ${ }^{235} \mathrm{U}$ の誘 導 FT の計数結果をウラン濃度の指標としてい た。当初は同じ粒子で熱中性子照射前後で FT

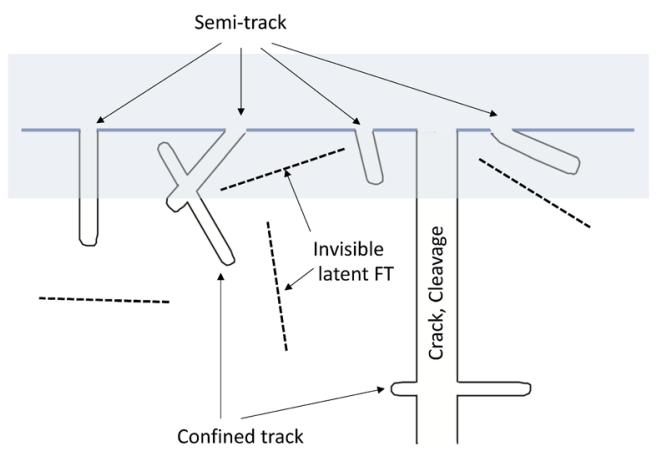

Fig. 3 Schematic cross section of a sample with FT after etching. Uranium in shaded zone contributes to the number of observed FT on the surface, but some of them (dotted line) do not reach the observed surface. The registration factor reflects the width of shaded zone and chance of FT reaching to the observed surface. 
を計数したり (re-etch 法) ${ }^{8,21)}$ ，粒子群を二つ に分けて一方で自発 FT を他方をアニーリング ののち熱中性子照射して誘導 FT を観察してい た (population 法) ${ }^{26)}$ 。 ${ }^{235} \mathrm{U}$ の誘導 FT 鉱物中 ではなく外部ディテクターに記録させ，鉱物で 自発 FT を, 外部ディテクターで誘導 FTを計 数することも当時すでに実施されていた（External Detector Method: EDM) ${ }^{26)}$ 。これらの手法は, $\mathrm{U}$ 濃度の指標も面積あたりの FT の計数に依っ ており，単位体積あたりの FT 数を見積もる 必要がなかったという点で, 正に state-of-theart といってよい手法だった。しかし全 ${ }^{235} \mathrm{U}$ 中, 誘導核分裂した割合の見積もりに，原子炉内で の熱中性子量やその空間分布及び時間変化，熱 中性子のエネルギー分布とその時間変化, 反 応断面積の測定などを伴い ${ }^{48)}$ ，いずれも一筋 縄ではいかないという難点があった。さらに, 2000 年代になるまで ${ }^{238} \mathrm{U}$ の自発核分裂壊変定 数が確定していなかったこと ${ }^{49-51)}$ から, これら の不確定な定数をまとめて年代標準試料の分析 により実験的に求めるら較正法が推奨されてお

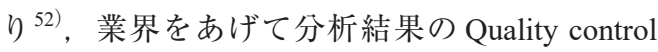
が成されていた。また後に明らかになったこと だが，自発 FT と誘導 FT で若干 registration factor が異なる (FT 長が異なる) こと ${ }^{14,15,53,54)}$ 及 び外部検出器に対しても registration factor が異 なっていること ${ }^{55,56)}$ から， 較正法の適用はこ れらに起因する年代值のズレを生じさせなかっ た点でも優れていた。

較正法での年代式は以下になる。

$$
t=\frac{1}{\lambda} \ln \left(G \zeta \lambda \frac{\rho_{s}}{\rho_{i} / \rho_{d}}+1\right)
$$

(6) 式の ${ }^{238} U$ の個数の代わりに対象試料中の 誘導 FT の単位面積当たりの数 $\rho_{i}$ を, ウラン濃 度既知の標準ガラス中の誘導 FT の単位面積当 たりの数 $\rho_{d}$ で規格化したものを採用している。 その際に必要となる係数 (原子炉照射条件によ る）及び $\lambda_{\mathrm{f}}$ や registration factor $(k)$ をまとめて一 つの変数らとしている。このらは, 年代既知の
試料の分析により決める実験定数である。

$$
\zeta=\frac{\rho_{i, s t d} / \rho_{d}}{G \lambda \rho_{s, s t d}}\left(e^{\lambda t_{s t d}}-1\right)
$$

なお， $t_{s t d}$ は年代既知試料の推奨年代， $\rho_{i, s t d}$ と $\rho_{s, s t d}$ は年代既知試料から得られた誘導 FT と自 発 FT の密度である。

最近は原子炉での熱中性子照射に伴う不便さ （放射性物質の取り扱い，照射・冷却に伴う実 験期間の長期化，利用可能な研究炉の減少）か ら，ウラン濃度測定に LA-ICP-MS（レーザーア ブレーション誘導結合プラズマ質量分析装置) を利用することも増えてきた。LA-ICP-MS を 用いてウラン濃度を測定する際の年代式には現 在 $2 つ の$ 考え方がある。一つ目は (6) 式を利用 し，単位体積あたりの自発トラックが観察面に 現われる割合 $(k G)$ に基づき, 観察面で計数し た自発 FT 数から単位体積あたりの自発 FT 数 を求め, それと LA-ICP-MS 測定で求めたウラ ン濃度から作る年代式である ${ }^{57)}$ 。これにより, FT 法にとって長年の希望であった，年代標準 試料に依存しない独立した年代測定 ${ }^{58-60)}$ が可 能になる。もう一つの考え方は，較正法によ る（10）式，（11）式と同様，年代標準試料の分 析結果から実験的に定数を決めてやり, LAICP-MS 測定のカウント数と観察面で計数した 自発 FT 数からなる年代式を構築するものであ る $^{19,61,62) 。(10) ~}$ 式にある $\rho_{i}$ の代わりに試料のカ ウント数を, $\rho_{d}$ の代わりにウラン濃度既知の標 準ガラスのカウント数を用いる。LA-ICP-MS の 特質から, カウント数としては, ${ }^{238} \mathrm{U}$ と内部標 準同位体のカウント比を取ることが一般的で ある ${ }^{63)}$ 。独立した年代測定式(6)を利用する場 合, LA-ICP-MS 測定で得られたカウント数か らウラン濃度を計算する際には，多くの定数が 必要であり, これらの定数は実験によって求め られている。しかし，これらの定数の考え方に 現在では気づいていないバイアスが隠れている 可能性がある。加えて, $k G$ の絶対值を求める ことも容易ではない。これまでの較正法と同 
様, 年代標準試料に基づく定数を利用するやり 方は，これらのバイアスを避けることができる 利点がある。

現在のところ, 各実験室は独自の考え方に基 づいた年代式をそれぞれ利用している。分析機 関によって異なる年代值が報告されることは避 けなければならない。LA-ICP-MS 測定に基づ く FT 法は, 今後潜在するバイアスを整理し分 析法や年代式の標準化を進めることが必要とな る段階へ進むところである。

\section{$3 \cdot 5 \quad \mathrm{FT}$ 年代值の報告}

「はじめに」で述べたとおり，FT 法では単粒 子年代決定が当初から可能であったため, 一つ の試料から得る複数の年代值の取り扱いが重要 な研究対象であった。FT 年代值には放射壊変 がポアソン分布に従って発生することに起因す る䛊差が付随するため, 単一年代を持つはず の粒子群を分析しても，ばらつきを示す。その ばらつきが壊変に伴うものであるか, あるいは 異なる年代值が混入したものであるかの評価 法として, $\chi^{2}$ 検定が導入された ${ }^{47)}$ 。検定の結 果, 粒子年代のばらつきが放射壊変に伴うばら つきによるものだと判断されれば，全ての粒子 の自発 FTを足し合わせることにより得られる pooled age とよばれる年代值を, 試料の年代と 解釈することができる。またばらつきを視覚的 に認識するために, 確率密度分布 (age spectra とも呼ばれている ${ }^{4)}$ や radial plot ${ }^{64,65)}$ が導入さ れた (Fig. 4)。確率密度分布 (age spectra) は粒 子年代の誤差を考慮した確率密度分布を測定し た全粒子分足し合わせて得る。 radial plot は横 軸に誤差の逆数を, 縦軸に誤差で標準化した年 代值をとって作成する。試料に複数の年代成分 がある場合には，それを分離することも試みら れている ${ }^{65,66)}$ 。

\section{FT 長を利用した熱履歴解析}

\section{$4 \cdot 1 \quad$ FT 長測定}

これまでは主として年代測定に関係する内
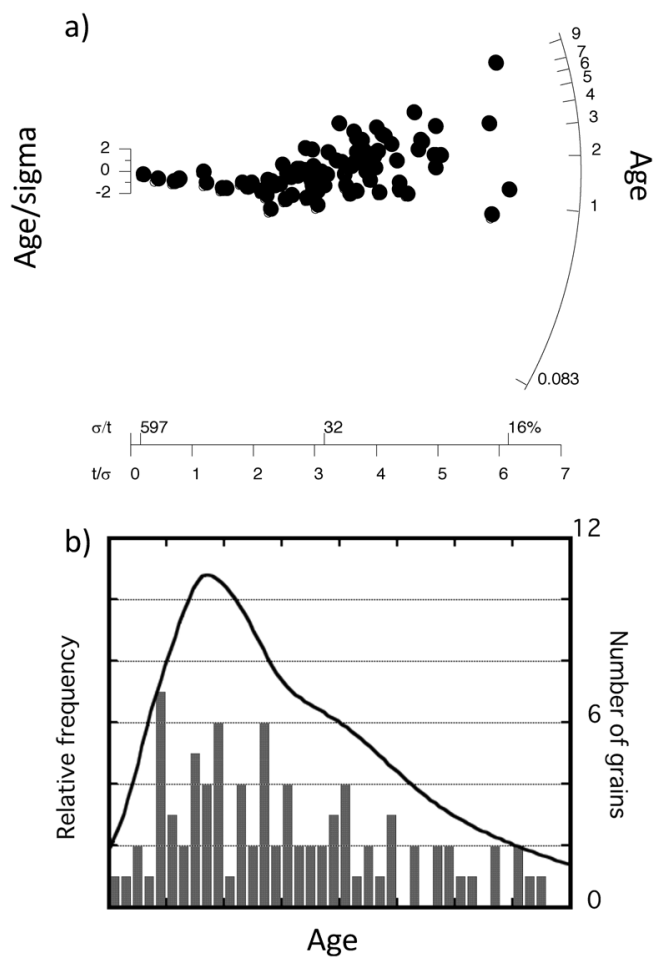

Fig. 4 Example of (a) radial plot and (b) age spectra with histogram.

容について紹介してきたが，実はFT 法の最大 の長所は FT の長さ観察に基づく試料の熱履歴 解析にある。エッチングされた FTには, 観察 面に露出しておりその長さを一部失っている もの（semi-track）と, 試料中で FT の両端が確 認でき全長を保存しているもの (confined track) がある (Fig. 3)。confined track は割れ目や semitrack と交わっている場合にエッチングされ 測定が可能になる。前者を Track-in-cleavage (TINCLE)，後者を Track-in-track（TINT）と呼 ぶ。ジルコンとアパタイトは熱履歴解析に必 要な FT の熱に対する挙動がよく研究されてお り，その研究成果に基づいて得られた分析結果 の解釈を行う際は，同じエッチング条件を適用 することが強く推奨される。

以下に FT 長測定の要点をまとめる ${ }^{19,67,68)}$

・熱履歴解析の際は confined trackを測定す るが, 鉱物の割れ目などに沿って, 天然 条件下でエッチングが起こりうるので, 
TINCLE の使用は避けた方が良い。

・FTのエッチングとアニーリングには異方 性があるので，長さだけでなく結晶学的方 位の測定も必要。

・エッチングの進行により, 観察される FT の長さと幅が大きくなっていくので，エッ チングの条件及び測定に用いる confined track 選定の規準（幅など）を明確にする。

\section{4·2 FT アニーリングの定性的記述}

FT は固体中に存在する非晶質な線状損傷で あるため, 温度上昇により熱拡散速度が上がる と結晶構造が修復されていき，損傷である FT は徐々に消滅する。透過型電子顕微鏡 (TEM) を用いたその場観察により，非晶質部分を構成 する原子と点欠陥が加熱により拡散・移動し再 結晶化することが明らかになっている41)。ま た, 実験室で加熱されたFT をエッチングし光 学顕微鏡で全長を観察することにより，FT は アニーリングの初期段階では両端から短縮する が,さらにアニーリングが進むと断片状になっ て消滅していくと考えられている ${ }^{33)}$ 。

実験室での加熱実験から明らかになったア ニーリング特性の要点は以下のようにまとめら れる67)。

(1)FTのアニーリングには異方性があり, ア パタイトとジルコン共に C 軸方向ではア ニーリング速度が遅い(アニーリングさ れにくい)。

(2)アニーリング速度は化学組成にも依存し, $\mathrm{Cl}$ の多いアパタイトではアニーリング速 度が遅い（詳細は本特集号の末岡ほか参 照)。

(3) 異なるエッチング剂を用いると観察上ア ニーリング速度が異なるように見える (例えばスフェーンの $\mathrm{HCl}$ vs $\mathrm{NaOH}$ 溶液 の場合) ${ }^{67)}$ 。

(4) 誘導 FT の生成直後の加熱実験から, ア パタイト中の FT は常温でもわずかにア ニーリングされることが知られている。
(5)アニーリング速度は放射線損傷の蓄積量 や圧力に依存する可能性がある（詳細は 本特集号の末岡ほか参照)。

また，天然条件下でさらに明らかになったア ニーリング特性の要点は以下のように追加され る $^{67)}$ 。

(6)自発 FT と誘導 FT の加熱実験前の長さ は, ジルコンとスフェーンでは一致する が,アパタイトでは一致せず自発FTの 方が有意に短い。これはアパタイト中 の FT が常温下に長時間置かれると少し アニーリングされるためと考えられ，上 記 (4)の観察事実と整合的である。

(7)地質学的時間スケールでアニーリングさ れた自発FTのエッチング像や短縮過程 は, 実験室時間での FT アニーリングの 結果と違いが見られず, 同一の素過程に よることが示唆される。

(8) 実験で確立されたアニーリング関数の地 質学的時間スケールへの外挿結果は，天 然条件下でのアニーリング結果と基本的 に一致する。ただし正確な FT 長測定と 化学組成評価が必須である（詳細は本特 集号の末岡ほか参照)。

\section{4·3 FT アニーリングの定量的記述}

FT のアニーリングは基本的には熱拡散によ り支配されるので，FT 長の短縮は被熱の時間 と温度の関数として与えられる。初期の研究で は一次の速度論で記述されたが, その後, より 高次の速度論に従うことが明らかになった。加 えて, FTの年代值から推定するよりも精度よ く熱アニーリングを記述できることから，現在 では confined track 長を用いて熱アニーリング の速度論関数 (annealing kinetics) を決定してい る $^{67)}$ 。

FT のアニーリングは高次の速度論に従うた め, 通常の希ガスの拡散実験などに用いられる 等時間加熱だけでは速度論関数を正確に決定で きない。そこで，実験条件（温度と時間）を制 
御して加熱を行い，エッチングした FT 長の短 縮率 (形成時の長さで規格化した FT 長) デー 夕と加熱温度・加熱時間を速度論関数でフィッ ティングし係数を決定する。研究の初期では 縦軸に加熱時間 $(\mathrm{t})$ の対数, 横軸に絶対温度 $(\mathrm{T})$ の逆数をとった疑似アレニウス図上 (本号の 末岡ほか Fig. 3 参照) で, 単純な線形関数が使 われた ${ }^{69)}$ 。最近ではよりよくフィッティング させるために，様々な関数形が検討されてい る ${ }^{70-72)}$ 。

FT は高温で拡散速度が上がると，より短い 時間でその損傷が修復される。試料が高温状態 にあるときには核分裂が発生してもできた損傷 はすぐに修復されてしまいFT は残らない。こ のような温度領域を total annealing zone (TAZ) とよぶ。一方温度が低い状態では損傷の修復 は全く起こらないか検出できない程度にしか 発生しない。この温度領域を total stability zone （TSZ）とよぶ。その二つの間は partial annealing zone (PAZ) とよばれる。この温度領域では損 傷の部分修復が行われ, 結果としてエッチング 後の FT 長の短縮が発生する温度領域である。 $\mathrm{PAZ}$ の温度・時間範囲は上述のアニーリング 関数により近似的に与えられ，鉱物毎に大きく 異なる。地質学的な時間スケール $\left(10^{6}-10^{8}\right.$ 年) における PAZ は, アパタイトで約 60-120 ${ }^{\circ} \mathrm{C}^{73)}$, ジルコンで約 280-360 $\mathrm{C}^{71,72,74)}$ である。PAZ の地質学的意味と, それを用いた準定量的な 温度履歴解析の概要は末岡・田上 $(2019)^{4)}$, Tagami $(2012)^{75)}$ などで参照されたい。

\section{4・4 FT データを用いた熱史インバージョン}

上述のアニーリング関数が確立されると, 順 計算や逆計算による FT データの解析から地質 体の定量的な熱史復元 (熱史インバージョン) が可能となる。FTは時間とともに増加するの で，個別の FT 毎に辿ってきた熱史が異なり， 現在観察できる FT の長さ分布はそれらを全て まとめたものを見ている。FT 長が短縮・消滅 した場合，それに連動して観察面で計数できる
FT の数も減少し年代が若くなる ${ }^{31)}$ 。試料の熱 履歴は, 得られた FT 長分布と FT の数を最も よく説明するものを見出すことによって明らか にする。その中心となるのが FT 長データであ り，その分布形は PAZ 付近の熱史の違いをよ く反映するため, 定量的な熱史の絞り込みを効 果的に行うことができる ${ }^{76)}$ (Fig. 5)。特に，ア パタイトの FT 解析が堆積盆の石油熟成度評価 に広く有用であるため, 1980 年代後半から爆 発的に広まった。この解析に広く用いられて きたソフトウェアとして, Monte Trax ${ }^{77)}$, AFTSolve ${ }^{78)}$, 及びそれらの後継版である QTQt ${ }^{79)}$, $\mathrm{HeFTy}^{80)}$ がある。FT 解析ソフトウェア全般の 最新動向については本特集号の末岡他を参照さ れたい。熱史のモデル計算手順の概要（順計算 の場合）を以下に示す ${ }^{80)}$ 。

(1)鉱物種ごとにFTの熱アニーリングを時 間と温度を变数とした関数として記述す る。

（2）上記の記述式を熱史モデリングのアルゴ リズムに取り入れ, 時間と温度の関数と して FT 年代と FT 長分布の変化を記述す る順計算モデルを構築する ${ }^{76,80)}$ 。

(3)モンテカルロ法などにより熱史をランダ ムに数多く発生させ，それぞれの熱史に 対して FT 年代と FT 長分布を計算する。 それらの計算值を, 試料の分析により得 られる観測值と比較し, 良好な適合度を 持つ熱史だけを抽出する。

\section{5. 基礎研究の提案}

手法として成熟している FT 年代測定法であ るが，その黎明期を振り返ってみると，取りこ ぼしてしまった研究の方向性がある。ここでは 今後の FT 法の発展に貢献可能な内容について 2 つ提案する。

\section{$5 \cdot 1$ 黒雲母 FT 分析の熱年代学的可能性}

雲母類については初期の頃 FT 観察例が多く 報告されたが13,23-25), 現在ではアパタイトや 

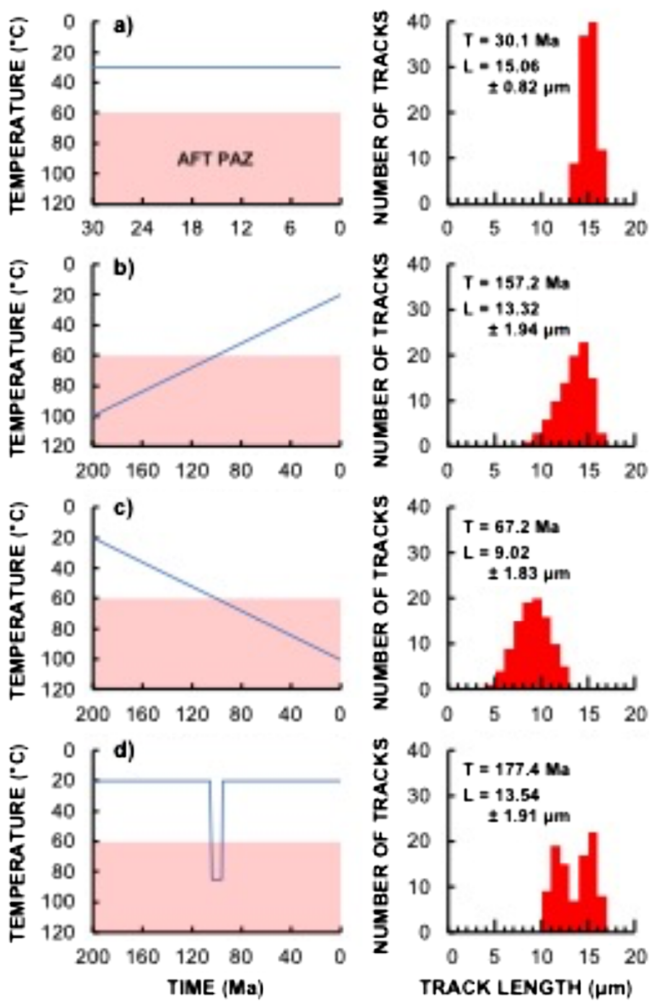

Fig. 5 Modeled thermal histories and resultant apatite FT length distributions from Sueoka and Taga$\mathrm{mi}^{4)}$. Original data is from Green et al. ${ }^{76)}$ a) When the temperature is lower than the partial annealing zone (PAZ), all tracks retain their original length. b) When a sample was monotonically cooled from the PAZ, tracks formed during the temperature being in PAZ were shortened in various extent depending on the time of track formation, and tracks formed during the temperature being lower than PAZ retain original length. c) When a sample was heated to PAZ, all tracks are shortened, but tracks formed later in the PAZ are a little longer due to shorter heating duration. d) When a sample experienced a flash heating event, tracks formed before the event were shortened and tracks after the event retain original length (Color online).

ジルコンに比較してあまり利用されていない。 その理由の一つは, 雲母類は $\mathrm{K}-\mathrm{Ar}$ 法で年代決 定できたからではないかと思われる。FT 年代 值の誤差はFTの計数に依存しており，放射壊 変イベントがポアソン分布に従うことに基づき 誤差が与えられる ${ }^{47)}$ 。一方 K-Ar 法は分析誤差
に基づき年代誤差が見積もられているので，分 析手法の発展に伴い誤差が少ない值を報告でき る。そのため，わざわざ䛊差の大きい FT 法で 年代值を求めようとする取り組みが進まなかっ たのではないかと思われる。また当時は熱年代 学の概念がまだ十分発展していなかったため, 閉鎖温度の異なる複数の年代測定法を用いるこ との重要性があまり認識されていなかったこと も，雲母類 FT 法の利用に研究者の目が向かわ なかった遠因になったのではと思う。黒雲母で は ${ }^{235} \mathrm{U}$ の誘導 FT を用いたアニーリング実験で 閉鎖温度を求める実験の例があり，アパタイト

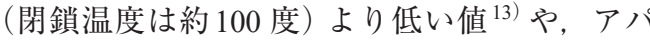
タイトとジルコンの間の值 ${ }^{25)}$ が報告されてい る。現在は研究が止まっている黒雲母の FT 法 を進めることにより, 低温の熱年代学の武器を 増やすことができるかもしれない。

\section{$5 \cdot 2$ 鉱物分離をしない FT 法の可能性}

ウラン濃度測定に LA-ICP-MS を利用すると 原子炉での照射を必要としないため, 鉱物の単 離は必ずしも必要ではない。例えば断層岩にお ける研究のように, 岩石の組織と年代值の関係 が重要になる場合は観察用に用意した薄片内の 対象鉱物の年代決定が必要となることがある。 そこで鉱物分離を伴わない FT 年代測定の可能 性について紹介する。

アパタイトが対象の場合，エッチングを弱い 硝酸で短時間で実施できるので，構造を観察し た薄片での年代決定が可能である。

FT 法でよく利用されるジルコンの場合は，強 アルカリ（NaOH：KOH）共融液で $200^{\circ} \mathrm{C}$ 以上の 高温でのエッチングを数時間行うことが必要で あり ${ }^{81)}$ ，薄片全体をエッチング溶液に浸すこ とは不可能である。しかし $\mathrm{KOH}: \mathrm{NaOH}: \mathrm{LiOH}$ （モル比 14:6:1）共融液 ${ }^{82,83)}$ を利用すると, $150^{\circ} \mathrm{C}$ でもエッチングが可能であるため，これ を薄片中の対象鉱物がある部位に作用させるこ とによってエッチングが可能になるかもしれな い ${ }^{84)}$ 。ただしジルコンは微量鉱物であるため, 
薄片中に認められるのは稀であり，応用範囲は 狭い。雲母やガラスなどフッ酸をエッチングに 用いる場合も，試料全体を薬品に浸すのでは なく, 対象部位に薬品をのせる方法をとると, エッチングが可能であると思われる。雲母類は 主要鉱物の一つであるため, 岩石組織や構造を 観察するために用意した薄片にもよく認められ る。鉱物分離を施さない FT 観察を雲母類を対 象に行うのも面白い取り組みとなるかもしれな い。

\section{6. おわりに}

本稿では主として FT 法の黎明期の研究成果 に立ち返り, その中から今後の FT 法の発展に 貢献可能な内容について紹介した。表層変動 研究に有効な手法として成熟した FT 法である が, 黎明期に行われた様々な研究の中には, そ の後の発展が見达まれるものの，十分尽くされ ていない内容も見受けられ, 特に雲母類の FT 法については, 熱年代学の視点からもっと研究 されても良いのではと思われる。FTをどう認 定するかは古くて新しい問題であり, 本稿では すべては触れていないが，ジルコンやアパタイ 卜を実用的に分析できるように手法を高めた先 人の取り組みに心より敬意を表したい。また認 知度が高くなってきた LA-ICP-MS を利用した ウラン濃度測定については, コミュニティ内で の規格化の議論を進める段階にきている。FT 法は光学顕微鏡と LA-ICP-MS もしくは研究用 原子炉へのアクセスが確保されていれば，比較 的始めるのに敷居が低い手法である。多くの方 に FT 法に興味を持ってもらい研究者の裾野が 広がることが，新たな発見や熱年代手法として の発展に不可欠である。

\section{謝 辞}

豊田新教授 (岡山理科大学) には貴重なコメ ントをいただいた。

\section{文 献}

1) 兼岡一郎, 年代測定概論, pp. 315, 東京大学出 版会，東京 (1998)

2) Faure, G. and Mensing, T. M., Isotopes: Principles and Applications, pp. 928, Wiley and Sons, Inc., New Jersey (2004)

3) Green, P. F., Duddy, I. R., Gleadow, A. J. W. and Lovering, J. F., Apatite fission-track analysis as a paleotemperature indicator for hydrocarbon exploration, In Naeser, N. D. and McCulloh, T. H. (eds.), Thermal History of Sedimentary Basins. Methods and Case Histories., pp. 181-195, Springer-Verlag, New York (1989)

4) Brandon, M. T., Decomposition of fission-track grain-age distributions, Am. J. Sci., 292, 535-564 (1992)

5) Gleadow, A. J. W., Duddy, I. R., Green, P. F. and Hegarty, K. A., Fission track lengths in the apatite annealing zone and the interpretation of mixed ages, Earth Planet. Sci. Lett., 78, 245-254 (1986)

6) Hurford, A. J., An historical perspective on fissiontrack thermochronology, In Malusà, M. G. and Fitzgerald, P. G. (eds.), Fission-Track Thermochronology and its Application to Geology., pp. 3-23, Springer International Publishing AG, Switzerland (2019)

7) Kohn, B., Chung, L. and Gleadow, A., Fission-track analysis: field collection, sample preparation and data acquisition, In Malusà, M. G. and Fitzgerald, P. G. (eds.), Fission-Track Thermochronology and Its Application to Geology., pp. 25-48, Springer International Publishing AG., Switzerland (2019)

8) 檀原 徹, 第四紀テフラの高精度フィッショ ン・トラック (FT) 年代測定—ジルコンとガラ スを用いた測定法の確立に向けて一，第四紀研 究, 34, 221-237 (1995)

9) 末岡 茂, 田上高広, 低温領域の熱年代学の原 理と地殼浅部のテクトニクスへの応用, 地学雑 誌, 128, 707-730 (2019)

10) Fleischer, R. L., Price, P. B. and Walker, R. M., Nuclear tracks in solids, Sci. Am., 220, 30-39 (1969)

11) Silk, E. C. H. and Barnes, R. S., Examination of fission fragment tracks with an electron microscope, Philos. Mag., 4, 970-972 (1959)

12) Yada, K., Tanji, T. and Sunagawa, I., Radiation induced lattice defects in natural zircon ( $\mathrm{ZrSiO}$ (sub 4)) observed at atomic resolution, Phys. Chem. Miner., 14, 197-204 (1987) 
13) Nagpaul, K. K., Mehta, P. P. and Gupta, M. L., Annealing studies on radiation damages in biotite, apatite and sphene and corrections to fission track ages, Pure Appl. Geophys., 112, 131-139 (1974)

14) Gleadow, A. J. W., Duddy, I. R., Green, P. F. and Lovering, J. F., Confined fission track lengths in apatite: a diagnostic tool for thermal history analysis, Contrib. Mineral. Petrol., 94, 405-415 (1986)

15) Hasebe, N., Tagami, T. and Nishimura, S., Towards zircon fission track thermochronology: Reference framework for confined track length measurements, Chem. Geol. Isot. Geosci. Sect., 112, 169-178 (1994)

16) Iwano, H. and Danhara, T., A re-investigation of the geometry factors for fission-track dating of apatite, sphene and zircon, In van den Haute, P. and De Corte, F. (eds.), Advances in Fission-Track Geochronology., pp. 47-66, Kluwer Academic Publishers, Netherlands (1998)

17) Reimer, G. and Carpenter, B., Thorium Determination in Glasses using Fission Track Technique, $\mathrm{Na}$ ture, 247, 101-102 (1974)

18) Tagami, T., Lal, N., Sorkhabi, R. B., Ito, H., et al., Fission track dating using external detector method: A laboratory procedure. Mem. Fac. Sci., Kyoto Univ. Ser. Geol. Mineral., 53, 14-30 (1988)

19) Donelick, R. A., O' Sullivan, P. B. and Ketcham, R. A., Apatite fission-track analysis, Rev. Mineral. Geochem., 58, 49-94 (2005)

20) Price, P. B. and Walker, R. M., Observation of fossil particle tracks in natural micas, Nature, 196, 732 734 (1962)

21) Fleischer, R. L. and Price, P. B., Techniques for geological dating of minerals by chemical etching of fission fragment tracks, Geochim. Cosmochim. Acta, 28, 1705-1714 (1964)

22) Fleischer, R. L., Price, P. B. and Walker, R. M., Tracks of charged particles in solids, Science, $\mathbf{1 4 9}$, 383-393 (1965)

23) Welin, E., Lundström, I. and Åberg, G., Fission track studies on hornblende, biotite and phlogopite from Sweden, Bull. Geol. Soc. Finl., 44, 35-46 (1972)

24) Qureshi, A. A., Karim, T., Rizvi, S. H. N., Tahir, M., et al., Fission track dating of biotite mica from Antarctica, Radiat. Meas., 25, 521-522 (1995)

25) Saini, H. S., Sharma, O. P. and Nagpaul, K. K., Track annealing characteristics of biotite mineral, Mineral. J., 11, 21-31 (1982)

26) Naeser, C. W. and Dodge, F. C. W., Fission-track ages of accessory minerals from granitic rocks of the
Central Sierra Nevada Batholith, California, Geol. Soc. Am. Bull., 80, 2201-2212 (1969)

27) Giese, J., Seward, D., Stuart, F. M., Wüthrich, E., et al., Electrodynamic disaggregation: Does it affect apatite fission-Track and (U-Th)/He analyses? Geostand. Geoanal. Res., 34, 39-48 (2010)

28) 檀原 徹, 岩野英樹, 糟谷正雄, 山下透, 他, 無毒な重液 SPT (ポリタングステン酸ナトリウ ム）とその利用。地質ニュース， 55, 31-36 (1992)

29) 長谷部徳子, LST の試用, フィッション・ト ラックニュースレター, 12, 43-44 (1999)

30) Sumii, T., Tagami, T. and Nishimura, S., Anisotropic etching character of spontaneous fission tracks in zircon, Nucl. Tracks Radiat. Meas., 13, 275-277 (1987)

31) Green, P. F., The relationship between track shortening and fission track age reduction in apatite: combined influences of inherent instability, annealing anisotropy, length bias and system calibration, Earth Planet. Sci. Lett., 89, 335-352 (1988)

32) Yamada, R., Tagami, T. and Nishimura, S., Assessment of overetching factor for confined fission track length measurement in zircon, Chem. Geol. Isot. Geosci. Sect., 104, 251-259 (1993)

33) Yamada, R., Tagami, T. and Nisimura, S., Confined fission-track length measurement of zircon: Assessment of factors affecting the paleotemperature estimate, Chem. Geol., 119, 293-306 (1995)

34) Barbarand, J., Hurford, T. and Carter, A., Variation in apatite fission-track length measurement: implications for thermal history modelling, Chem. Geol. 198, 77-106 (2003)

35) Naeser, C. W., The use of apatite and sphene for fission track age determinations, Geol. Soc. Am. Bull., 78, 1523-1526 (1967)

36) Gleadow, A. J. W., Anisotropic and variable track etching characteristics in natural sphenes, $\mathrm{Nucl}$. Track Detect., 2, 105-117 (1978)

37) Coyle, D. A. and Wagner, G. A., Positioning the titanite fission-track partial annealing zone, Chem. Geol., 149, 117-125 (1998)

38) Westgate, J. A., Isothermal plateau fission track ages of hydrated glass shards from silicic tephra beds, Earth Planet. Sci. Lett., 95, 226-234 (1989)

39) Bigazzi, G., Neto, J. C. H., Iunes, P. J. and Araya, A. M. O., Fission-track dating of South American natural glasses: An overview, Radiat. Meas., 39, 585-594 (2005)

40) Ito, K. and Hasebe, N., Fission track dating of Quaternary volcanic glass by stepwise etching, Radiat. 
Meas., 46, 176-182 (2011)

41) Paul, T. A. and Fitzgerald, P. G., Transmission electron microscopic investigation of fission tracks in fluorapatite, Am. Mineral., 77, 507-511 (1992)

42) Hadler, J. C., Alencar, I. J., Iunes, P. and Guedes, S., Glass fission track analysis by AFM and SEM: Inferring latent track structure through etched tracks, Radiat. Meas., 44, 746-749 (2009)

43) Kohlmann, F., Gleadow, A. J. W., Kohn, B. P., Alves, A., et al., Atomic force microscopy of fission tracks in fluorapatite and mica: A tool for nanoscale investigations, Geochim. Cosmochim. Acta, 70(Supplement 1), A327 (2006)

44) Kohlmann, F., Kohn, B. P., Gleadow, A. J. W. and Siegele, R., Scanning force microscopy of ${ }^{129}$ Iodine surface impact structures in muscovite, zircon and apatite as proxies for damage of simulated fission fragments in solids, Radiat. Meas., 51-52, 83-91 (2013)

45) Ohishi, S. and Hasebe, N., Observations of fissiontracks in zircons by atomic force microscope, Radiat. Meas., 47, 548-556 (2012)

46) 長谷部徳子, Barbarand, J., Carter, A., Hurford, A. J., LA-ICP-MS FT 年代測定法のための年代式の展 開，フィッショントラックニュースレター，16, $1-5$ (2003)

47) Green, P. F., A new look at statistics in fission-track dating, Nucl. Tracks, 5, 77-86 (1981)

48) Green, P. F. and Hurford, A. J., Thermal neutron dosimetry for fission track dating, Nucl. Tracks, 9 , 231-241 (1984)

49) Bigazzi, G., The problem of the decay constant of ${ }^{238} \mathrm{U}$, Nucl. Tracks, 5, 35-44 (1981)

50) Holden, N. E. and Hoffman, D. C., Spontaneous fission half-lives for ground-state nuclides (Technical Report), Pure Appl. Chem., 72, 1525-1562 (2000)

51) Yoshioka, T., Tsuruta, T., Iwano, H. and Danhara, T., Spontaneous fission decay constant of ${ }^{238} \mathrm{U}$ determined by SSNTD method using CR-39 and DAP plates, Nucl. Instrum. Methods Phys. Res. A, 555, 386-395 (2005)

52) Hurford, A. J., Standardization of fission track dating calibration: Recommendation by the Fission Track Working Group of the I. U. G. S. Subcommission on Geochronology, Chem. Geol. Isot. Geosci. Sect., 80, $171-178(1990)$

53) Gleadow, A. J. W., Belton, D. X., Kohn, B. P. and Brown, R.W., Fission track dating of phosphate minerals and the thermochronology of apatite, Rev.
Mineral. Geochem., 48, 579-630 (2002)

54) Donelick, R. A., Crystallographic orientation dependence of mean etchable fission track length in apatite: An empirical model and experimental observations, Am. Mineral., 76, 83-91 (1991)

55) Iwano, H., Kasuya, M., Yamashita, T. and Danhara, T., One-to-one correlation of fission tracks between zircon and mica detectors, Nucl. Tracks Radiat. Meas., 20, 341-347 (1992)

56) Jonckheere, R. and Van den haute, P., On the efficiency of fission-track counts in an internal and external apatite surface and in a muscovite external detector, Radiat. Meas., 35, 29-40 (2002)

57) Hasebe, N., Barbarand, J., Jarvis, K., Carter, A., et al., Apatite fission-track chronometry using laser ablation ICP-MS, Chem. Geol., 207, 135-145 (2004)

58) Hurford, A. J. W., Zeta: The ultimate solution to fission-track analysis calibration or just an interim measure? In van den Haute, P. and De Corte, F. (eds.), Advances in Fission-Track geochronology., pp. 19-32 Kluwer Academic Publishers, Dordrecht, The Netherlands (1998)

59）檀原 徹，岩野英樹，独立した FT 年代測定の 確立: LA-ICPMS-FT 法に向けてのここ 10 年の 歩み, 月刊地球号外， 62,111-116(2013)

60) Iwano, H., Danhara, T. and Hirata, T., Standardless fission-track age of the IUGS age standards, Chem. Geol., 488, 87-104 (2018)

61) Hasebe, N., Tamura, A. and Arai, S., Zeta equivalent fission-track dating using LA-ICP-MS and examples with simultaneous U-Pb dating, Isl. Arc, 22, 280291 (2013)

62) Cogné, N., Chew, D. M., Donelick, R. A. and Ansberque, C., LA-ICP-MS apatite fission track dating: A practical zeta-based approach, Chem. Geol., 531, $119302(2020)$

63) Jarvis, K. E. and Williams, J. G., Laser ablation inductively coupled plasma mass spectrometry (LAICP-MS): A rapid technique for the direct, quantitative determination of major, trace and rare-earth elements in geological samples, Chem. Geol., 106, 251-262 (1993)

64) Galbraith, R. F., Graphical display of estimates having differing standard errors, Technometrics, $\mathbf{3 0}$, 271-281 (1988)

65) Vermeesch, P., RadialPlotter: A Java application for fission track, luminescence and other radial plots, Radiat. Meas., 44, 409-410 (2009)

66) Galbraith, R. F. and Green, P. F., Estimating the 
component ages in a finite mixture, $\mathrm{Nucl}$. Tracks $\mathrm{Ra}$ diat. Meas., 17, 197-206 (1990)

67) Tagami, T. and O' Sullivan, P. B., Fundamentals of fission-track thermochronology, Rev. Mineral. Geochem., 58, 19-47 (2005)

68) Tagami, T., Zircon fission-track thermochronology and applications to fault studies, Rev. Mineral. Geochem., 58, 95-122 (2005)

69) Laslett, G. M., Green, P. F., Duddy, I. R. and Gleadow, A. J. W., Thermal annealing of fission tracks in apatite 2. A quantitative analysis, Chem. Geol. Isot. Geosci. Sect., 65, 1-13 (1987)

70) Ketcham, R. A., Donelick, R. A. and Carlson, W. D., Variability of apatite fission-track annealing kinetics III: Extrapolation to geological time scales, Am. Mineral., 84, 1235-1255 (1999)

71) Yamada, R., Murakami, M. and Tagami, T., Statistical modelling of annealing kinetics of fission tracks in zircon; Reassessment of laboratory experiments, Chem. Geol., 236, 75-91 (2007)

72) Ketcham, R. A., Fission-track annealing: from geologic observations to thermal history modeling, In Malusà, M. G. and Fitzgerald, P. G. (eds.), FissionTrack Thermochronology and its Application to Geology., pp. 49-75, Springer International Publishing AG, Switzerland, (2019)

73) Gleadow, A. J. W., Duddy, I. R. and Lovering, J. F., Fission track analysis: A new tool for the evaluation of thermal histories and hydrocarbon potential, J. Austr, Petrol. Product. \& Explor. Assoc., 23, 93-102 (1983)

74) Tagami, T., Galbraith, R. F., Yamada, R. and Laslett, G. M., Revised annealing kinetics of fission tracks in zircon and geological implications, in: van den Haute, P. and De Corte, F. (eds.), Advances in Fission-track Geochronology., pp. 99-112, Kluwer Academic Publishers, Dordrecht, The Netherlands (1998)

75) Tagami, T., Thermochronological investigation of fault zones, Tectonophysics, 538-540, 67-85 (2012)

76) Green, P. F., Duddy, I. R., Laslett, G. M., Hegarty, K. A., et al., Thermal annealing of fission tracks in apatite 4. Quantitative modeling techniques and extension to geological timescales, Chem. Geol. Isot. Geosci. Sect., 79, 155-182 (1989)

77) Gallagher, K., Evolving thermal histories from fis- sion track data, Earth Planet. Sci. Lett., 136, 421-435 (1995)

78) Ketcham, R. A., Donelick, R. A. and Donelick, M. B., AFTSolve: A program for multi-kinetic modeling of apatite fission-track data, Geol. Mater. Res., 2 (2000)

79) Gallagher, K., Transdimensional inverse thermal history modeling for quantitative thermochronology, $J$. Geophys. Res., 117(B2), B02408 (2012)

80) Ketcham, R. A., Forward and inverse modeling of lowtemperature thermochronometry data, Rev. Mineral. Geochem., 58, 275-314 (2005)

81) Gleadow, A. J. W., Hurford, A. J. and Quaife, R. D., Fission track dating of zircon: improved etching techniques, Earth Planet. Sci. Lett., 33, 273-276 (1976)

82) Zaun, P. E. and Wagner, G. A., Fission-track stability in zircons under geological conditions, Nucl. Tracks Radiat. Meas., 10, 303-307 (1985)

83) Garver, J. I., Etching zircon age standards for fissiontrack analysis, Radiat. Meas., 37, 47-53 (2003)

84) 小山博晃, 長谷部徳子, ジルコンの薄片エッチ ングをめざした取り組み, フィッション・ト ラックニュースレター, 33, 36-39 (2020)

\section{Abstract}

\section{Radiometric Dating Methods Using Natural Radiation Damage}

Basics of Fission-track Geo- and Thermo-chronometry: Revisiting Its History to Explore Future Potential

Noriko HASEBE $^{1, \dagger}{ }^{\dagger}$, Shigeru SUEOKA ${ }^{2}$ and Takahiro TAGAMI ${ }^{3}$ : ${ }^{1}$ Institute of Nature and Environmental Technology, Kanazawa University, ${ }^{2}$ Tono Geoscience Center, Japan Atomic Energy Agency, ${ }^{3}$ Division of Earth and Planetary Sciences, Graduate School of Science, Kyoto University, ${ }^{\dagger}$ hasebe@staff.kanazawa-u.ac.jp

Fission-track (FT) method observes linear dislocations in geological materials formed by nuclear fission of ${ }^{238} U$. FT method provides information on thermal history of a sample below $300^{\circ} \mathrm{C}$, together with geological dates. This report revisits the development history of FT method and suggests potential research target left unearthed. 